\title{
Studi Kelayakan Penilaian Kinerja Institusi dengan Pendekatan Balanced Scorecard di Politeknik Negeri Bandung
}

\author{
Hastuti $^{\mathrm{a}^{*}, \text { Sholihati Amalia }}{ }^{\mathrm{b}}$, Sumiyati ${ }^{\mathrm{c}}$ \\ a Jurusan Akuntansi, Politeknik Negeri Bandung, spi@polban.ac.id, Indonesia
}

\begin{abstract}
Kinerja organisasi harus senantiasa dievaluasi. Evaluasi kinerja organisasi dengan pendekatan tradisonal lebih menitikberatkan pada unsur keuangan saja. Hal ini dianggap tidak komprehensif dan tidak dapat mewakili kinerja organisasi secara keseluruhan. Pendekatan balanced scorecard merupakan alat ukur kinerja organisasi dengan empat perspektif yang ada di organisasi. Keempat perspektif itu adalah perspektif keuangan, perspektif pelanggan, perspektif proses bisnis internal dan perspektif pembelajaran dan pertumbuhan. Alat ukur ini bisa diimplementasikan pada organisasi berorientasi laba atau organisai nirlaba. Polban merupakan salah satu perguruan tinggi pemerintah dengan akreditasi sangat baik "A". Selama ini Polban melakukan evaluasi kinerjanya dengan panduan aturan pemerintah berupa laporan akuntabilitas kinerja institusi pemerintah (LAKIP). Penyusunan LAKIP merupakan pekerjaan yang sifatnya mandatory (penugasan) dari Kemenristekdikti. Penelitian ini telah menilai kesiapan Polban untuk melakukan evaluasi kinerja secara mandiri dengan pendekatan balance scorecard. Berdasarkan hasil studi dokumentasi, observasi, dan wawancara maka disimpulkan Polban dapat mengevaluasi kinerjanya dengan keempat perspektif balance scorecard. Dengan peendekatan ini Polban dapat mengevaluasi kinerjanya secara mandiri dan berkesinambungan.
\end{abstract}

Keywords: balanced scorecard, LAKIP, perspektif keuangan, perspektif pelanggan, perspektif proses bisnis internal, perspektif pembelajaran dan pertumbuhan

\section{Pendahuluan}

Kinerja merupakan istilah umum yang digunakan untuk menunjukkan sebagian atau seluruh tindakan atau aktivitas dari suatu organisasi pada suatu periode tertentu. Kinerja juga diartikan sebagai luaran atau hasil dari kegiatan atau program yang hendak atau telah dicapai sehubungan dengan penggunaan anggaran dengan kuantitas dan kualitas yang terukur (PP No. 8 tahun 2006).

Sebagai sebuah capaian, kinerja organisasi haruslah dinilai atau dievaluasi. Ini berlaku bagi semua organisasi, berorientasi laba atau organisasi nirlaba. Evaluasi kinerja pada umumnya dilakukan dengan pendekatan tradisional yaitu pengukuran kinerja yang bersumber dari informasi keuangan. Namun, evaluasi kinerja berdasarkan pendekatan tradisional mempunyai beberapa kelemahan, antara lain tidak berorientasi pada kepentingan jangka panjang melainkan berorientasi pada kepentingan jangka pendek serta ketidakmampuan dalam mengukur kekayaan-kekayaan yang sifatnya tidak berwujud maupun kekayaan intelektual (sumber daya manusia). Kaplan dan Norton (2000) menilai ini sebagai sebuah kelemahan dan dapat diantisipasi dengan melakukan pengukuran pada masing-masing perspektif yang ada dalam organisasi yaitu perspektif keuangan, perspektif pelanggan, perspektif proses bisnis internal, serta perspektif pembelajaran dan pertumbuhan. Keempat perspektif tersebut dikembangkan sebagai salah satu alat ukur kinerja organisasi, yaitu dengan pendekatan balanced scorecard. Walaupun fokus dan aplikasi awal balanced scorecard adalah organisasi laba, peluang balanced scorecard untuk dipakai dalam memperbaiki manajemen perusahaan pemerintah dan perusahaan nirlaba mungkin bahkan lebih besar.

\footnotetext{
*Corresponding author. E-mail: spi@polban.ac.id
} 
Organisasi pemerintah adalah pengguna anggaran pemerintah yang ditujukan untuk memberikan layanan publik. Dalam rangka pertanggungjawaban pelaksanaan penggunaan anggaran pemerintah (APBN/APBD) setiap instansi pemerintah wajib menilai kinerja organisasinya. Hal ini merupakan amanah dari PP No. 8 tahun 2006 tentang Pelaporan Keuangan dan Kinerja Instansi Pemerintah.

Evaluasi kinerja yang telah dilakukan belum meliputi keempat perspektif dimaksud. Penelitian ini menilai kesiapan Polban untuk melakukan evaluasi kinerja dengan pendekatan balance scorecard. Evaluasi ini dapat dilakukan bila didukung oleh bagian atau unit terkait dan terutama oleh seluruh civitas akademika Polban, yang kelak akan merasakan manfaatnya.

Berdasarkan hal di atas maka dilakukan penelitian untuk mengevaluasi kinerja Polban dari semua perspektif organisasi dengan pendekatan balanced scorecard. Agar penilaian kinerja lebih komprehensif, dan bermanfaat untuk kepentingan jangka panjang.

\section{Tinjauan Pustaka}

Konsep pengukuran kinerja pada organisasi sektor publik adalah bertujuan untuk membantu manajer publik menilai pencapaian suatu strategi melalui alat ukur finansial dan non finansial. Pengukuran kinerja sektor publik dilakukan untuk memperbaiki kinerja pemerintah, pengalokasian sumber daya dan pembuatan keputusan, dan mewujudkan pertanggungjawaban publik serta memperbaiki komunikasi pelanggan.

Pengukuran kinerja sektor publik dilakukan untuk memenuhi tiga maksud. Pertama, pengukuran kinerja sektor publik dimaksudkan untuk memperbaiki kinerja pemerintah. Ukuran kinerja dimaksudkan untuk dapat membantu pemerintah berfokus pada tujuan dan sasaran program unit kerja. Hal ini pada akhirnya akan meningkatkan efisiensi dan efektifitas organisasi sektor publik dalam pemberian pelayanan publik.

Kedua, ukuran kinerja sektor publik digunakan untuk pengalokasian sumber daya dan pembuatan keputusan. Ketiga, ukuran kinerja sektor publik dimaksudkan untuk mewujudkan pertanggungjawaban publik dan memperbaiki komunikasi pelanggan (Mardiasmo, 2002:121).

\section{Balanced Scorecard}

Balanced scorecard merupakan sebuah sistem manajemen untuk mengimplementasikan strategi, mengukur kinerja yang tidak hanya dari sisi finansial semata melainkan juga melibatkan sisi non finansial, serta untuk mengkomunikasikan visi, strategi, dan kinerja yang diharapkan. Dengan kata lain pengukuran kinerja tidak dilakukan semata-mata untuk jangka pendek saja, tetapi juga untuk jangka panjang (Kaplan dan Norton, 2005). Balanced scorecard menunjukkan adanya metode pengukuran kinerja yang menggabungkan antara pengukuran keuangan dan non keuangan. Mulyadi (2001) menilai bahwa balanced scorecard adalah alat mengukur strategi secara komprehensif dengan pola manajemen strategis dan perangkat manajemen kontemporer yang digunakan untuk meningkatkan kemampuan organisasi dalam melipatgandakan kinerja keuangan.

Pada tahap perkembangannya balanced scorecard dimanfaatkan untuk setiap tahap sistem manajemen strategik, sejak tahap perumusan strategi sampai tahap implementasi dan pemantauan (Mulyadi, 2001). Pada tahap perumusan strategi (strategy formulation), balanced scorecard digunakan untuk memperluas cakrawala dalam menafsirkan hasil penginderaan terhadap trend perubahan lingkungan makro dan lingkungan industri ke perspektif yang lebih luas: keuangan, pelanggan, proses bisnis internal, serta pembelajaran dan pertumbuhan.

Melalui empat perspektif balanced scorecard, manajemen mampu menafsirkan dampak trend perubahan lingkungan bisnis yang kompleks terhadap misi, visi, dan tujuan (goals) perusahaan. Di samping itu, pada tahap perumusan strategi, rerangka balanced scorecard juga dimanfaatkan untuk melakukan analisis SWOT (strengths, weaknesses, opportunities, and threats). Analisis SWOT dilaksanakan melalui empat perspektif balanced scorecard tersebut, manajemen dapat secara komprehensif memperoleh gambaran kekuatan dan kelemahan oleh perusahaan serta peluang dan ancaman yang dihadapi oleh perusahaan di masa depan.

Pada tahap perencanaan strategik (strategic planning), balanced scorecard digunakan untuk menerjemahkan strategi ke dalam sasaran-sasaran strategik yang komprehensif, koheran, seimbang dan terukur. Dalam tahap perencanaan strategik ini pula dirumuskan inisiatif strategik untuk mewujudkan sasaran-sasaran strategik.

Pada tahap penyusunan program (programming), balanced scorecard digunakan untuk menjabarkan 
inisiatif strategik di empat perspektif ke dalam program. Dengan balanced scorecard dapat dihasilkan rencana jangka panjang yang komprehensif yang mencakup perspektif keuangan, pelanggan, proses bisnis internal serta pembelajaran dan pertumbuhan. Pada tahap penyusunan anggaran (budgeting), balanced scorecard digunakan untuk menjabarkan program ke dalam anggaran sehingga anggaran yang dihasilkan juga bersifat komprehensif.

Di samping itu, alasan organisasi sektor publik mengadopsi balanced scorecard, karena perspektif non finansial merupakan penilaian yang lebih menentukan dalam mencapai misinya sehingga ukuran ini dapat dipakai dalam organisasi sektor publik. Keberhasilan organisasi sektor publik harus diukur dengan seberapa efisien dan efektif mereka memenuhi kebutuhan konstituennya, tujuan tangible (berwujud) harus didefinisikan untuk pelanggan dan konstituennya. Karena itu untuk menilai kinerja organisasi sektor publik diperlukan banyak pendekatan selain pendekatan finansial juga pendekatan non finansial karena tujuan organisasi sektor publik bukan pada laba namun pelayanan konsumen sehingga perspektif finansial bukan kendala.

\section{Pengukuran Kinerja dengan Balanced Scorecard}

Pengukuran kinerja dengan balanced scorecard merupakan alternatif pengukuran kinerja yang didasarkan pada empat perspektif utama, yaitu keuangan, pelanggan, proses bisnis internal, pembelajaran dan pertumbuhan. Kelebihan penggunaan balanced scorecard adalah bahwa dengan pendekatan balanced scorecard berusaha untuk menterjemahkan misi dan strategi perusahaan ke dalam tujuan-tujuan dan pengukuran-pengukuran yang dilihat dari empat perspektif yaitu keuangan, pelanggan, proses bisnis internal, pembelajaran dan pertumbuhan tersebut.

\section{Perspektif Keuangan}

Sasaran-sasaran perspektif keuangan dibedakan pada masing-masing tahap dalam siklus bisnis yang oleh Kaplan dan Norton (2000) dibedakan menjadi tiga tahap: 1) growth (berkembang), 2) sustain stage (bertahan) dan harvest (panen). Prinsip ini bisa diimplementasikan pada organisasi sektor publik sebagai:

a. memperoleh hasil usaha atau hasil kerja dari layanan yang diberikan (rentabilitas); b. memenuhi kewajiban jangka pendeknya (likuiditas);

c. memenuhi seluruh kewajibannya (solvabilitas);

d. kemampuan penerimaan dari jasa layanan untuk membiayai pengeluaran.

\section{Perspektif Pelanggan}

Kinerja dalam perspektif pelanggan berkaitan dengan bagaimana menciptakan persepsi yang baik dari pandangan pelanggan dengan tujuan untuk meningkatkan kepercayaan dan kepuasan pelanggan terhadap perusahaan. Kaplan dan Norton (2000: 58) menjelaskan pengukuran dalam perspektif pelanggan, yaitu menurut pangsa pasar, akuisisi pelanggan, retensi pelanggan, dan tingkat kepuasan pelanggan.

\section{Perspektif Proses Bisnis Internal}

Menurut Kaplan dan Norton (2000: 83) dalam proses bisnis internal, manajer harus bisa mengidentifikasi proses internal yang penting di mana perusahaan diharuskan melakukan dengan baik karena proses internal tersebut mempunyai nilai-nilai yang diinginkan konsumen dan dapat memberikan pengembalian yang diharapkan oleh para pemegang saham. Tahapan dalam proses bisnis internal meliputi 1) inovasi yaitu seberapa besar upaya yang dilakukan perusahaan dalam berinovasi, 2) proses operasional yaitu tahap di mana perusahaan berupaya memberikan solusi kepada pelanggan dalam memenuhi kebutuhan dan keinginan pelanggan.

\section{Perspektif Pembelajaran dan Pertumbuhan}

Perspektif pembelajaran dan pertumbuhan berkaitan dengan kinerja pegawai dalam melaksanakan pekerjaannya. Menurut Kaplan dan Norton unsur-unsur pada perspektif ini adalah 1) kepuasan karyawan, 2) kemampuan sistem informasi, 3) motivasi, pemberdayaan dan keselarasan.

Sebagai sebuah alat ukur, keempat perspektif di atas saling berhubungan. Dimulai dengan perspektif pembelajaran dan pertumbuhan. Bila perspektif ini sudah ada pada perusahaan, maka akan ada suatu strategi untuk meningkatkan produktivitas dan komitmen karyawan. Sebagai akibat dari peningkatan produktivitas dan komitmen dari karyawan akan meningkat pula kualitas proses layanan pelanggan dan proses layanan pelanggan akan terintegrasi. Dengan demikian kepercayaan pelanggan dan kepuasan pelanggan akan meningkat pula yang menaikan perspektif pelanggan. Kemudian akhirnya akan berpengaruh pada perspektif keuangan yang ditunjukkan dengan peningkatan pendapatan 
penjualan, peningkatan cost effectiveness, dan peningkatan laba. Jadi dari masing-masing perspektif memiliki peran dan hubungan yang tidak dapat dipisahkan satu sama lain. Perspektif keuangan sangat dipengaruhi oleh tiga perspektif lainya yaitu pembelajaran dan bertumbuh, pelanggan, serta internal bisnis.

Jika digambarkan maka perspektif yang ada dalam konsep ini akan terangkum sebagai berikut:

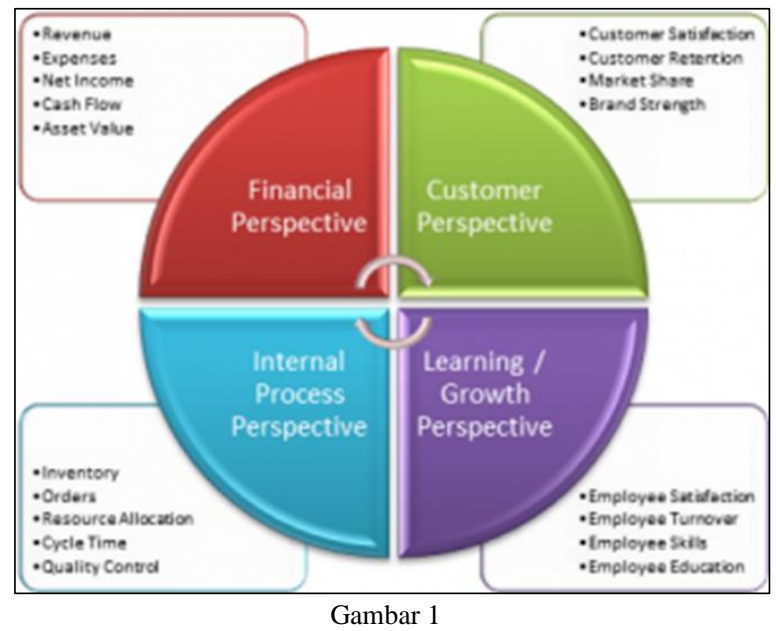

\section{Pengukuran Kinerja di Instansi Pemerintah}

Instansi pemerintah sebagai pengguna anggaran negara, wajib melaporkan kinerja instansinya kepada masyarakat. Keharusan itu tertuang pada Inpres No.7 Tahun 1999 tentang Akuntabilitas Instansi Pemerintah. Peraturan ini terus berkembang, dan sampai dengan saat ini, semua intansi pemerintah wajib menyusun LAKIP (Laporan Akuntabilitas Kinerja Instansi Pemerintah) yang merupakan luaran dari SAKIP (Sistem Akuntabilitas Kinerja Instansi Pemerintahan).

SAKIP adalah Sistem Akuntabilitas Kinerja Instansi Pemerintahan, di mana sistem ini merupakan integrasi dari sistem perencanaan, sistem penganggaran dan sistem pelaporan kinerja, yang selaras dengan pelaksanaan sistem akuntabilitas keuangan. Dalam hal ini, setiap organisasi diwajibkan mencatat dan melaporkan setiap penggunaan keuangan negara serta kesesuaiannya dengan ketentuan yang berlaku.

\section{Metode Penelitian}

Metode penelitian yang digunakan adalah deskriptif analisis, dengan jenis penelitian kualitatif. Unit analisis adalah Politeknik Negeri Bandung. Data yang digunakan berupa data subjek dan data dokumenter. Data subjek yang akan dikumpulkan berupa pendapat atau opini dari civitas akademika Polban yaitu dari mahasiswa, dosen dan karyawan. Sementara data dokumenter yang dikumpulkan adalah laporan keuangan Polban, LAKIP Polban untuk tahun anggaran 2016. Data subjek dan data dokumenter tersebut dikumpulkan untuk memperoleh informasi tentang ketersediaan data dalam rangka menghitung menganalisis perspektif pelanggan (mahasiswa), perspektif internal bisnis (dosen dan karyawan) dan perspektif pembelajaran dan pertumbuhan (mahasiswa, dosen dan karyawan). Sumber data pada penelitian ini adalah data primer yang diperoleh secara langsung tanpa perantara dari civitas akademika Polban. Sumber data sekunder diperoleh dari bagian keuangan, SPI Polban dan bagian arsip Polban. Data subjek dikumpulkan melalui wawancara pada responden dan wawancara langsung untuk responden terpilih. Sedangkan data dokumenter akan dikumpulkan melalui teknik dokumentasi.

Instrumen pada penelitian ini adalah daftar pertanyaan penelitian. Pertanyaan penelitian ini dikembangkan berdasarkan operasionalisasi variabel penelitian. Data dikumpulkan haruslah menunjang pada kesiapan Polban untuk melakukan evaluasi kinerja dengan pendekatan balanced scorecard. Data yang dibutuhkan berdasarkan operasionalisasi variabelnya adalah:

\begin{tabular}{|c|c|c|c|}
\hline Variabel & Dimensi & Indikator & $\begin{array}{l}\text { Skala } \\
\text { Ukur }\end{array}$ \\
\hline \multirow{11}{*}{$\begin{array}{l}\text { Balance } \\
\text { Scorecard } \\
\text { (Kaplan } \\
\text { dan } \\
\text { Norton, } \\
2000 \text { ) }\end{array}$} & \multirow{4}{*}{$\begin{array}{l}\text { Perspektif } \\
\text { Keuangan }\end{array}$} & Rasio Rentabilitas & Rasio \\
\hline & & Rasio Likuiditas & Rasio \\
\hline & & Rasio Solvabilitas & Rasio \\
\hline & & $\begin{array}{l}\text { Rasio Cost } \\
\text { Recovery }\end{array}$ & Rasio \\
\hline & \multirow{3}{*}{$\begin{array}{l}\text { Perspektif } \\
\text { Pelanggan }\end{array}$} & Akusisi Pelanggan & Rasio \\
\hline & & Retensi Pelanggan & Rasio \\
\hline & & $\begin{array}{l}\text { Tingkat Kepuasan } \\
\text { Pelanggan }\end{array}$ & Ordinal \\
\hline & \multirow{2}{*}{$\begin{array}{l}\text { Perspektif } \\
\text { Internal Bisnis }\end{array}$} & Inovasi & Rasio \\
\hline & & Kualitas Pelayanan & Rasio \\
\hline & \multirow{2}{*}{$\begin{array}{l}\text { Perspektif } \\
\text { Pembelajaran } \\
\text { dan } \\
\text { Pertumbuhan }\end{array}$} & Retensi Karyawan & Rasio \\
\hline & & $\begin{array}{l}\text { Kapabilitas } \\
\text { Karyawan }\end{array}$ & Rasio \\
\hline
\end{tabular}

Semua data yang dikumpulkan berskala rasio. Kecuali untuk satu jenis indikator, yaitu tingkat 
kepuasan pelanggan berskala ordinal. Indikator tersebut diukur dengan menggunakan data subjek yang berasal dari kuesioner yang telah disebar kepada responden. Tingkat kepuasan pelanggan diukur dengan menggunakan instrumen yang dikembangkan oleh Zeithaml dan Berry (1996) yaitu service quality (servqual) yang terdiri dari lima dimensi, yaitu dimensi wujud fisik (tangibels), keandalan (reliability), daya tanggap (responsiveness), jaminan (assurance), empati (emphaty). Kuesioner disusun dengan 5 skala likert dan disebarkan kepada mahasiswa. Kuesioner diuji validitas dan reliabilitasnya sebelum digunakan.

\section{Hasil dan Pembahasan}

Sebagai Perguruan Tinggi Negeri Polban diwajibkan mengukur kinerja instistusinya. Pengukuran kinerja institusi ini belumlah secara berkesinambungan dilakukan.

Pengukuran kinerja baru dilakukan bila dibutuhkan untuk kepentingan akreditasi institusi ataupun untuk kepentingan yang sifatnya mandatory (penugasan) dari Kementerian atau struktur organisasi di atasnya. Evaluasi kinerja belum dirasakan sebagai sebuah kebutuhan institusi baik secara bersama/isntitusi maupun civitas akademika yang ada di dalamnya.

Jika dilihat manfaat dari mengevaluasi kinerja institusi adalah: 1) untuk memperbaiki kinerja pemerintah; 2) untuk dapat membantu pemerintah berfokus pada tujuan dan sasaran program unit kerja; 3) untuk meningkatkan efisiensi dan efektifitas organisasi sektor publik/Polban dalam pemberian pelayanan publik.

Pendekatan balance scorecard diimplementasikan pada evaluasi kinerja di Polban adalah sebagai berikut.

\section{Evaluasi Kinerja pada Perspektif Keuangan}

Pada perspektif keuangan kinerja dikelompokan menjadi tiga tahap yaitu 1) growth (berkembang); 2) sustain stage (bertahan); dan 3) harvest (panen). Tahapan di atas biasa diimplemetasikan pada organisasi berorientasi laba. Pada organisasi sektor publik, terdapat aturan yang relevan tentang hal ini, yaitu Peraturan Menteri Dalam Negeri Nomor 61 tahun 2007 pasal 128 yang menyatakan bahwa evaluasi kinerja dai aspek keuangan dapat diukur berdasarkan tingkat kemampuan organisasi dalam:

a. Memperoleh hasil usaha atau hasil kerja dari layanan yang diberikan (rentabilitas); b. Memenuhi kewajiban jangka pendeknya (likuiditas);

c. Memenuhi seluruh kewajibannya (solvabilitas)

d. Kemampuan penerimaan dari jasa layanan untuk membiayai pengeluaran

Keempat ukuran tersebut dapat dilakukan oleh Polban. Hal ini didukung oleh telah tersedianya laporan keuangan Polban, di mana Polban telah menerapkan Peraturan Pemerintah No. 71 tahun 2010 tentang Standar Akuntansi Pemerintahan Berbasis Akrual secara penuh. Laporan keuangan Polban telah terintegrasi dan telah berbasis sistem informasi. Sebagai PTN, Polban telah menyusun laporan keuangannya dengan menggunakan aplikasi SAIBA (Sistem Akuntansi Instansi Berbasis Akrual) dan terintegrasi dengan baik pada aplikasi Persediaan dan SIMAK BMN (Sistem Informasi Manajemen dan Akuntansi Keuangan-Barang Milik Negara).

Laporan yang dihasilkan dari SAIBA pada Satker Polban adalah:

1) Laporan Realisasi Anggaran

2) Laporan Neraca

3) Laporan Operasional

4) Laporan Perubahan Ekuitas

5) Catatan Atas Laporan Keuangan

Persprektif keuangan di atas dapat dihitung dengan rumus sebagai berikut:

a. Likuiditas

$$
\begin{aligned}
& \text { Current Ratio }=\frac{\text { aktiva lancar }}{\text { kewajiban lancar }} \times 100 \% \\
& \text { Quick Ratio }=\frac{\text { aset lancar }- \text { persediaan }}{\text { kewajiban lancar }} \times 100 \% \\
& \text { Cash Ratio }=\frac{\text { kas dan setara kas }}{\text { kewajiban lancar }} \times 100 \%
\end{aligned}
$$

b. Solvabilitas

$$
\begin{aligned}
& \text { DAR }=\frac{\text { total kewajiban }}{\text { total aset }} \times 100 \% \\
& \text { DER }=\frac{\text { total kewajiban }}{\text { total ekuitas }} \times 100 \%
\end{aligned}
$$

c. Rentabilitas

$$
\begin{aligned}
& \mathrm{ROA}=\frac{\text { surplus }}{\text { total aset }} \times 100 \% \\
& \mathrm{ROE}=\frac{\text { surplus }}{\text { total ekuitas }} \times 100 \%
\end{aligned}
$$

\section{d. Cost Recovery}

Cost Recovery Rate $=\frac{\text { pendapatan BLUD }}{\text { biaya operasional }} \times 100 \%$ 


\section{Evaluasi Kinerja pada Perspektif Pelanggan}

Evaluasi kinerja pada perspektif pelanggan dititikberatkan pada bagaimana menciptakan persepsi yang baik dari sudut pandang pelanggan. Ini dilakukan dengan tujuan untuk meningkatkan kepercayaan dan kepuasan pelanggan terhadap perusahaan/isntitusi. Pada perspektif ini Kaplan dan Norton (2000:58) mengelompokkan menurut pangsa pasar, akuisisi pelanggan dan tingkat kepuasan pelanggan.

Pelanggan Polban adalah mahasiswa. Dengan jumlah 11 jurusan dan 41 program studi, jumlah pelanggan senantiasa meningkat dari tahun ke tahun. Polban telah membuka pendaftaran melalui program seleksi tanpa tes/PMDK dengan dua pilihan yaitu jalur akademik dan jalur bidik misi. Selain itu juga terdapat pendaftaran reguler yaitu penerimaan seleksi mahasiswa baru/PSMB Polban. Program kelas kerja sama pun ada dengan beberapa perusahaan dan pemerintah daerah.

Dengan ruang lingkup yang luas tersebut menjadi hal yang penting jika Polban melakukan evaluasi kinerja dari kacamata mahasiswa. Pada persepektif ini dapat digunakan indikator yang ditawarkan oleh Kaplan dan Norton sebagai berikut:

a. Retensi Pelanggan

Tingkat retensi pelanggan dinilai kurang apabila retensi pelanggan mengalami penurunan, dinilai sedang apabila konstan dan fluktuatif dan dinilai baik apabila mengalami peningkatan.

Retensi Pelanggan $=\frac{\text { jumlah pelanggan tahun berjalan }}{\text { jumlah pelanggan tahun lalu }} \times 100 \%$

\section{b. Akuisisi Pelanggan}

Tingkat akuisisi pelanggan dinilai kurang apabila akuisisi pelanggan mengalami penurunan, dinilai sedang apabila konstan dan fluktuatif dan dinilai baik apabila mengalami peningkatan.

Akuisisi Pelanggan $=\frac{\text { jumlah pelanggan baru }}{\text { jumlah pelanggan }} \times 100 \%$

\section{c. Tingkat Kepuasan Pelanggan}

Untuk mengukur tingkat kepuasan pelanggan, dibutuhkan kuesioner yang disebarkan kepada mahasiswa. Kuesioner ini dikembangkan oleh Zeithaml dan Berry (1996) yang dinamakan Service Quality (servqual). Adapun rinciannya adalah sebagai berikut:
Tabel 2 Variabel Operasional Kepuasan Pelanggan

\begin{tabular}{|c|c|c|c|}
\hline Variabel & Dimensi & Indikator & $\begin{array}{l}\text { Skala } \\
\text { Ukur }\end{array}$ \\
\hline \multirow{14}{*}{$\begin{array}{c}\text { Kepuasan } \\
\text { Pelanggan } \\
\text { (Zeithaml } \\
\text { dan Berry, } \\
\text { 1996) }\end{array}$} & \multirow{3}{*}{$\begin{array}{l}\text { Wujud Fisik } \\
\text { (tangibels) }\end{array}$} & $\begin{array}{l}\text { Perlengkapan } \\
\text { kesehatan layak } \\
\text { digunakan }\end{array}$ & Ordinal \\
\hline & & $\begin{array}{l}\text { Sarana dan prasarana } \\
\text { memadai }\end{array}$ & Ordinal \\
\hline & & $\begin{array}{l}\text { Penampilan karyawan } \\
\text { yang baik }\end{array}$ & Ordinal \\
\hline & \multirow{3}{*}{$\begin{array}{l}\text { Keandalan } \\
\text { (reliability) }\end{array}$} & $\begin{array}{l}\text { Pelayanan yang } \\
\text { diberikan memuaskan }\end{array}$ & Ordinal \\
\hline & & $\begin{array}{l}\text { Keakuratan diagnosa } \\
\text { yang diberikan tim } \\
\text { medis }\end{array}$ & Ordinal \\
\hline & & $\begin{array}{l}\text { Keakuratan pemberian } \\
\text { obat }\end{array}$ & Ordinal \\
\hline & \multirow{3}{*}{$\begin{array}{l}\text { Daya Tanggap } \\
\text { (responsiveness) }\end{array}$} & $\begin{array}{l}\text { Pelayanan yang } \\
\text { diberikan tepat waktu }\end{array}$ & Ordinal \\
\hline & & $\begin{array}{l}\text { Reaksi terhadap } \\
\text { permintaan pelanggan } \\
\text { yang cepat }\end{array}$ & Ordinal \\
\hline & & $\begin{array}{l}\text { Kesiap siagaan } \\
\text { pegawai untuk } \\
\text { memberikan } \\
\text { pertolongan kepada } \\
\text { pelanggan }\end{array}$ & Ordinal \\
\hline & \multirow[b]{2}{*}{$\begin{array}{c}\text { Jaminan } \\
(\text { assurance })\end{array}$} & $\begin{array}{l}\text { Kemahiran dan } \\
\text { keterampilan tim } \\
\text { medis dalam } \\
\text { menangani pasien }\end{array}$ & Ordinal \\
\hline & & $\begin{array}{l}\text { Kemampuan tim } \\
\text { medis, baik praktik } \\
\text { maupun pengetahuan } \\
\text { dalam melaksanakan } \\
\text { tugas }\end{array}$ & Ordinal \\
\hline & \multirow{3}{*}{$\begin{array}{l}\text { Empati } \\
\text { (emphaty) }\end{array}$} & $\begin{array}{l}\text { Pegawai memberikan } \\
\text { perhatian kepada } \\
\text { pelanggan }\end{array}$ & Ordinal \\
\hline & & $\begin{array}{l}\text { Pegawai memahami } \\
\text { kebutuhan pelanggan }\end{array}$ & Ordinal \\
\hline & & $\begin{array}{l}\text { Keramahan pegawai } \\
\text { dalam melayani } \\
\text { pelanggan }\end{array}$ & Ordinal \\
\hline
\end{tabular}

Dalam operasionalisasi variabel ini, indikator tingkat kepuasan pelanggan untuk megukur perspektif pelanggan, diukur oleh instrumen pengukur dalam bentuk kuesioner yang memenuhi pernyataanpernyataan tipe skala likert. Skala ini paling cocok karena skala Likert digunakan untuk mengukur sikap, pendapat dan persepsi seseorang atau sekelompok orang tentang fenomena sosial.

Dengan skala Likert, maka dimensi yang akan diukur dijabarkan menjadi indikator variabel. Kemudian indikator tersebut dijadikan sebagai titik tolak ukur menyusun item-item instrumen yang dapat berupa pertanyaan atau pernyataan.

Untuk mengukur perspektif pelanggan Polban, haruslah ditetapkan jumlah responden yang tepat. Populasi yang ditetapkan adalah jumlah mahasiswa 
yang aktif di semua jurusan pada tahun penelitian. Teknik penarikan sampling, bisa dengan random sampling atau purposive random sampling.

Berikut adalah perhitungan sampel untuk mengukur tingkat kepuasan pelanggan dengan menggunakan rumus Slovin:

$$
n=\frac{N}{1+N e^{2}}
$$

Keterangan:

n: sampel

e: error

$\mathrm{N}$ : populasi

Jika diasumsikan pada tahun penelitian jumlah mahasiswa aktif adalah 6000 mahasiswa, maka hasil perhitungan sampel dengan cara slovin ini adalah:

$$
\begin{aligned}
& n=\frac{6000}{1+6000(0,10)^{2}} \\
& n=98
\end{aligned}
$$

Dari jumlah sampel tersebut kemudian ditetapkan sebarannya agar bisa mewakili suara pelanggan Polban secara komprehensif. Sampel bisa ditetapkan dari semua jurusan, terwakili dari setiap program studi yang ada.

\section{Evaluasi Kinerja pada Perspektif Proses Bisnis Internal}

Evaluasi kinerja pada perspektif ini menyarankan kepada pimpinan untuk dapat mengidentifikasi proses internal yang penting (kunci) dalam rangkaian layanan publik Polban, karena pada proses tersebut terdapat layanan utama yang diinginkan oleh pelanggan. Tahapan pada perspektif ini adalah: 1) inovasi yaitu seberapa besar upaya yang dilakukan institusi dalam berinovasi; 2) proses operasional yaitu tahap di mana institusi berupaya memberikan solusi kepada mahasiswa dalam memenuhi kebutuhan dan keinginan pelanggan.

Proses bisnis internal Polban sebagai PTN dapat diidentifikasi dari mulai penerimaan mahasiswa sampai dengan proses wisuda dan pemberian ijazah. Rangkaian bisnis itu terkait dengan aktivitas akademik Polban. Indentifikasi kegiatan dapat dilakukan dengan melihat kurikulum dan bekerja sama dengan Pembantu Direktur I bidang Akademik dan Sistem Penjaminan Mutu.

\section{Evaluasi Kinerja pada Perspektif Pembelajaran dan Pertumbuhan}

Evaluasi kinerja pada perspektif ini dilakukan dengan mengukur kinerja pegawai Polban dalam melaksanakan pekerjaan yang menjadi tugas dan fungsinya. Menurut Kaplan dan Norton, unsur-unsur pada perspektif ini adalah 1) kepuasan karyawan, 2) kemampuan sistem informasi, 3) motivasi, pemberdayaan dan keselarasan.

Tolok ukur yang digunakan untuk mengukur perspektif pembelajaran dan pertumbuhan adalah peningkatan kapabilitas karyawan dan peningkatan komitmen karyawan.

a. Retensi Karyawan

Penilaian ini dilakukan untuk menilai tingkat komitmen karyawan yang dapat dinilai dari tingkat retensi karyawan.

Retensi Karyawan $=\frac{\text { Jumlah karyawan yang keluar }}{\text { Total karyawan pada tahun berjalan }} \times 100 \%$

Tingkat retensi karyawan dinilai baik apabila selama periode pengamatan mengalami penurunan, dinilai cukup baik apabila fluktuatif dan dinilai kurang baik apabila mengalami peningkatan.

b. Kapabilitas Karyawan

Tingkat pelatihan karyawan dinilai baik apabila mengalami peningkatan, dinilai sedang apabila fluktuatif dan dinilai kurang apabila mengalami penurunan selama periode penelitian.

Kapabilitas Karyawan $=\frac{\text { Jumlah karyawan mengikuti pelatihan }}{\text { Jumlah karyawan tahun berjalan }} \times 100 \%$

\section{Menganalisis Balanced Scorecard}

Menurut Mulyadi (2001), terdapat 4 macam standar yang dapat digunakan untuk melakukan evaluasi yaitu kinerja masa lalu, sasaran sekarang, rerata industri, dan kinerja pesaing. Pada evaluasi kinerja Polban, dapat dibandingkan dengan menggunakan kinerja masa lalu, yaitu dengan cara membandingkan kinerja Polbant selama beberapa periode atau bisa disebut analisis trend. Analisis trend merupakan teknik analisis yang digunakan untuk mengetahui trendensi keadaan kinerja perusahaan, apakah menunjukkan kenaikan ataupun penurunan. Analisis trend dilakukan dengan menggunakan analisis hosrisontal (dinamis). Data yang digunakan adalah data tahunan yang biasanya hanya terdiri atas dua atau tiga priode saja. Hal ini disebabkan karena jika data yang digunakan 
melebihi tiga periode maka akan mengalami kesulitan dalam melakukan analisis secara lebih cepat. Sehingga pada disarankan menggunakan tiga periode tahun anggaran. Tujuan menggunakan analisis trend pada penelitian ini adalah untuk memahami arah atau kecenderungan suatu aspek dari waktu ke waktu. Adapun tahapan analisis datanya sebagai berikut:

1. Memaparkan dan menjelaskan data-data yang telah didapatkan, seperti data keuangan Polban, data karyawan, rekapitulasi data pelanggan, data rekapitulasi pelatihan serta data-data lain yang relevan untuk kemudian diolah sesuai dengan indikator masing-masing perspektif.

2. Menilai kinerja masing-masing perspektif apakah sudah baik, cukup baik ataupun masih kurang baik. Hal ini dilihat dari kecenderungan kenaikan, penurunan atau bahkan mengalami fluktuasi (turun naik tidak stabil).

3. Mengintrespestasikan hasil olahan data yang telah dianalisis dan dikaitkan dengan teori.

\section{Evaluasi Kinerja di Polban}

Evaluasi kinerja di Polban sudah dilakukan dengan menggunakan pendekatan yang ada pada LAKIP (Laporan Akuntabilitas dan Kinerja Institusi Pemerintah). Evaluasi ini bersifat mandatory (penugasan) dari Kemenritekdikti, dilakukan setiap tahun. Sebagai sebuah mandatory hasil evaluasi ini dirasakan belum menjadi kebutuhan Polban sebagai institusi dan semua civitas akademika. Idealnya evaluasi kinerja menjadi sebuah kebutuhan institusi dan semua individu yang ada di Polban. Apalagi civitas akademika Polban adalah aparatur sipil negara/ASN.

Hasil evaluasi kinerja yang ada pada LAKIP tidak disosialisasikan, sehingga tidak ada feedback dari semua pihak yang terlibat dan berhubungan dengan kinerja Polban. Ada beberapa unit, seperti PD I yang telah melakukan evaluasi kinerja dosen. Selain itu ada pula bagian kepegawaian yang melakukan evaluasi kinerja tenaga kependidikan baik PNS maupun kontrak. Namun semua bentuk evaluasi kinerja yang sudah dilakukan belum terintegrasi dengan baik.

Dengan mengevaluasi kinerja secara keseluruhan, maka Polban dapat melakukan perencanaan strategis untuk meningkatkan kinerjanya. Ini sangat bermanfaat sebagai masukan di tingkat pimpinan Polban.

\section{Penutup}

Kesimpulan penelitian ini adalah:

1. Evaluasi kinerja Polban dapat dilakukan dengan pendekatan balanced scorecard yang mengukur empat perspektif terdiri dari perspektif keuangan, perspektif pelanggan, perspektif proses bisnis internal dan perspektif pembelajaran dan pertumbuhan.

2. Pengukuran kinerja Polban selama ini belum dilakukan dengan keempat perspektif tersebut. Pengukuran kinerja dilakukan dengan pendekatan yang ada pada LAKIP (Laporan Akuntabilitas dan Kinerja Instansi Pemerintah).

Saran pada penelitian ini adalah:

1. Dapat dilakukan penelitian lanjutan untuk mengimplementasikan evaluasi kinerja dengan pendekatan balanced scorecard pada Politeknik Negeri Bandung.

2. Evaluasi kinerja harus dilakukan rutin menjadi sebuah kebutuhan institusi dan kebutuhan individu civitas akademika Polban sebagai bentuk pengembangan berkelanjutan (continuous improvement).

\section{References}

Kaplan, Robert S. dan Norton, David P. (2000). Balanced Scorecard: Menerapkan Startegi Menjadi Aksi. Terjemahan Oleh Peter R. Yosi Pasla. Jakarta: Erlangga.

Lestari, Sri. (2016). Pengukuran Kinerja Dengan Pendekatan Balanced Sorecard pada Rumah Sakit PKU Muhammdiyah Gombong. Universitas Negeri Yogyakarta.

Lynch, Richard L. dan Cross, Kelvin. (1993). Performance Measuremennt System, Handbook of Cost Management. New York: Warren Gorham Lamont.

Mahmudi. (2007). Manajemen Kinerja Sektor Publik. Yogyakarta: Sekolah Tinggi Ilmu Manajemen YKPN.

Mulyadi. (2001). Balanced Scorecard: Alat Manajemen Kontemporer untuk Pelipatgandaan Kinerja Keuangan Perusahaan. Jakarta: Salemba Empat.

Muthia Puspita Sari, Evaluasi Kinerja dengan Pendekatan Balanced Scorecard pada Rumah Sakit Berstatus Badan Layanan Umum Daerah, Tugas Akhir Tidak Dipublikasikan.

Peraturan Pemerintah No. 8 Tahun 2006 tentang Pelaporan Keuangan dan Kinerja Instansi Pemerintah.

Permenpan Nomor 29 Tahun 2010 Tentang Pedoman Penyusunan Penetapan Kinerja Dan Pelaporan Akuntabilitas Kinerja Instansi Pemerintah. 
Pramadhany, Wahyu Eko Y. (2011). Penerapan Metode Balanced Sorecard Sebagai Tolak Ukur Penilaian Kinerja Pada Organisasi Nirlaba. Universitas Diponegoro.

Rusdiyanto, Ahmad Falah. (2010). Analisis Kinerja dengan Pendekatan Balanced Scorecard. Universitas Diponegoro.

Sugiyono. (2015). Metode Penelitian Kuanttatif Kualitatif dan R\&D. Bandung: CV Alfabeta.

Santoso, Singgih. (2000). Buku Latihan SPSS Statistik Parametrik. Jakarta: PT.Elek Media Komputindo.

Zeithaml, Valarie A., Leonard L Berry, and A. Parasuraman. (1996) Behavior Consequences of Service Quality. Jurnal of Marketing, Vol 60.

(2017). Laporan Keuangan Polban. 